\title{
In-Vitro Effectiveness of Ethanol Extract of Permot Leaf (Passiflora foetida Linn.) Towards Mortality of Rhipicephalus sanguineus Larvae
}

\author{
${ }^{1)}$ Intan Nurcahya, ${ }^{2)}$ Poedji Hastutiek, ${ }^{3)}$ Ratna Damayanti, ${ }^{3)}$ Iwan Sahrial Hamid, ${ }^{4)}$ Agus Wijaya \\ 1)Student, Faculty of Veterinary Medicine, Universitas Airlangga, intannurcahya594@gmail.com \\ ${ }^{2)}$ Department of Veterinary Parasitology, Faculty of Veterinary Medicine, Universitas Airlangga \\ ${ }^{3)}$ Department of Basic Veterinary Medicine Faculty of Veterinary Medicine, Universitas Airlangga \\ ${ }^{3)}$ Veterinary Internal Medicine Division, Department of Clinic, Reproduction and Pathology, Faculty of \\ Veterinary Medicine, IPB University \\ Corresponding author: ratna-d@fkh.unair.ac.id
}

\begin{abstract}
This study had three fold objective which were finding the effectiveness of ethanol extract of permot leaf (Passiflora foetida Linn.) towards mortality of Rhpicephalus sanguineus ( $R$. sanguineus) larvae in vitro and also identifying lethal concentration and lethal time. Completely randomized design was used with six treatments and four replications. Five $R$. sanguineus were used in the treatment for all replication. The observation of mortality was done every ten minutes in five hours. Rhpicephalus sanguineus larvae were dead if there was no movement. The collected data was analyzed using ANOVA factorial and followed by Duncan's test. The obtained data showed that ethanol extract of permot's leaf ethanol extract was effective toward mortality of $R$. sanguineus larvae in vitro. The suspension of $10 \%$ extract concentration of permot leaf ethanol extract has a similar effectiveness as Noticks. Probit analysis stated that $\mathrm{LC}_{50}$ can be reached by using the $4 \%$ concentration in two hours and $2.4 \%$ concentration in five hours. $\mathrm{LC}_{95}$ can be reached by using the $6.5 \%$ concentration in two hours and $3.93 \%$ concentration in five hours. The quickest $\mathrm{LT}_{50}$ can be reached in 0.91 hours and $\mathrm{LT}_{95} 2.37$ hours after treatment with $10 \%$ concentration.
\end{abstract}

Keywords: ethanol extract, Permot leaf, in vitro, Rhipicephalus sanguineus, Passiflora foetida

\section{Introduction}

Permot plants have potential as biological larvicides. This plant grows wild and is found in large quantities in nature. Permot plants can be easily found in rice fields, gardens or growing vines between the main plants that are deliberately planted or propagated on fences (Susilowati and Sari, 2018). Indonesia is a country that has many plants that have benefits if explored properly. Permot (Passiflora foetida Linn.) is a plant that belongs to the types of weeds and shrubs. Permot leaf extract contains alkaloids, terpenoids and phenols. The flavonoids found in permot leaves include apigenin, ermanin, 7,4-dimethoxapigenin, isovitexin and viteksin. The group of alkaloids found in permot leaves include harmaline, hamine, harmol (Patel, 2011). Passiflora foetida contains alkaloids and approximately ten flavonoids, one of which is ermanin which caused the death of Nympalid Butterfly Dione Juno. The content of ermanin contained in this plant can be used to kill pests and insects (Echeverri et al., 2001). The tick R. sanguineus or commonly referred to as the Brown Dog Tick is a three-hosted tick that attacks dogs, cats, rabbits, rodensia, wild dogs, and humans (Dantas, 2008). Tick infestations in dogs affect the physical condition and health of dogs because the $R$. sanguineus can cause itching in the host so that the dog will be disturbed by this condition. If this condition is not treated, over time the dog will be stressed so that his appetite decreases, his weight decreases and he is susceptible to disease. Infestation of ticks on pets, especially dogs, can also cause economic losses because of the relatively high cost of treatment and must always be repeated to prevent re-infestation of the dog. Treatment for tick infestations is also not only for the host but also for the surrounding environment because the $R$. sanguineus tick is a tick that has three hosts. Rhpicephalus sanguineus tick infestation in dogs can cause hair loss, tick dermatitis, irritation, and trauma that make owners reluctant to play with their beloved dog (Puri et al., 2014) Tick infestations can cause severe anemia to the point of death in the host and can cause tick paralysis in the host. These ticks are vectors of disease agents such as Ehrlichia canis, 
Rickettsia ricketsii, and Rickettsia conorii which can cause zoonotic diseases (Dantas-Torres, 2008). Rhipicephalus sanguineus is also the main vector of blood protozoa that attack erythrocytes, namely Babesia canis in dogs (Lubis, 2006, in Paramita and Widyastuti, 2019). Control of tick infestations using chemical insecticides such as Coumaphos, Ivermectin, Diazinon, and other parasitic drugs often have side effects that can cause death if the insecticide levels used are not correct through contamination of drinking water, feed and air (Riyadi et al., 2018). Vegetable pesticides are pesticides whose basic ingredients are derived from plant secondary metabolites. The working system of plant-based pesticides kills pests in real time and will soon decompose in nature (Syakir, 2011). The use of bioacricides as a substitute for synthetic acaricides is expected to reduce environmental losses and pollution caused by the use of synthetic acaricides. Bioacicides have properties that are easily and quickly degraded by nature so that they do not cause residues that are harmful to the environment, humans and animals.

\section{Materials and Methods}

The samples used in this study were 120 larvae of $R$. sanguineus which were taken randomly from the rearing of female $R$. sanguineus in the engorged phase of dogs in East Java. Permot leaves that have been weighed with a weight of 7.5 kilograms are cut to get smaller sizes first. The small size can affect the speed in drying the leaves. Leaves aerated for approximately one week. After it is dry enough, the permot leaves are ground to get simplicia. Extraction was carried out by maceration method using 96\% ethanol. The dried simplicia was weighed as much as 1000 grams and then put into a maceration vessel. Ethanol was added in a maceration vessel containing permot leaf simplia then stirred and allowed to stand for $3 \mathrm{x}$ 24 hours. The extraction process stops if the solvent obtained is clear after the filtering process. The filtrate was concentrated using a rotary evaporator at a temperature of $50^{\circ} \mathrm{C}$ to obtain an extract that still contained a small amount of solvent. Evaporation was carried out using an oven at $40^{\circ} \mathrm{C}$ to obtain a thick extract (Patmasari et al, 2013). The thick extract was diluted according to the concentration to be used, namely 2.5\%; 5\%; 7.5\%; and 10\% (Prasetya, 2015). This study used a higher concentration of $10 \%$. $R$. sanguineus female taken from the dog was put into a medicine pot. Rhipicephalus sanguineus was then reared by placing it in a pot covered with gauze as a cover. During the rearing process the humidity needs to be maintained by wetting the gauze cover. Every day $R$. sanguineus was observed until the ticks lay eggs. Tick eggs are waited until they hatch into larvae. Larvae that hatch awaited until the age of 7 days. The 7-day-old $R$. sanguineus tick larvae were randomly assigned to six treatment groups and $20 R$. sanguineus larvae were placed in each treatment group which were divided into four petri dishes in each group. Each petri dish contained five $R$. sanguineus larvae. The negative control group was sprayed using aquadest + Tween $801 \%$. The positive control group was sprayed using Noticks ${ }^{\circledast}$ containing $80 \%$ Coumaphos. The first treatment group was sprayed with a suspension of $2.5 \%$ concentration of Permot leaf ethanol extract. The second treatment group was sprayed with a suspension of Permot leaf ethanol extract with a concentration of $5 \%$. The third treatment group was sprayed with a suspension of $7.5 \%$ permot leaf ethanol extract. The fourth treatment group was sprayed using a suspension of $10 \%$ permot leaf extract. Spraying is carried out five times with the same pressure and a distance of $5 \mathrm{~cm}$ from the top of the larva. Observations of mortality were carried out every 10 minutes for 5 hours. The data obtained were analyzed using two-way and one-way analysis of variance (ANAVA), followed by Duncan's multipledistance test to compare the mean larval mortality. Lethal concentration and Lethal Time were analyzed using probit analysis. Statistical analysis was carried out using the SPSS 20 program.

\section{Results and Discussion}

The results of observations made on the mortality rate of $R$. sanguineus larvae based on various treatments and associated with the fastest required time of death can be seen in Table 1.

The death of $R$. sanguineus larvae was indicated by the larvae's legs rolling inward (Wardhana, 2005) and there was no movement. Signs of larval death with rolled legs can be seen in Figure 1.

It can be seen in Table 1 that the use of ethanol extract of permot leaves also showed effective results on the mortality of $R$. sanguineus larvae although they had different levels of effectiveness. 
Table 1. Average Mortality and Standard Deviation Observation of Mortality of R.sanguineus Larvae

\begin{tabular}{|c|c|c|c|c|c|c|}
\hline \multirow{2}{*}{ No. } & \multirow{2}{*}{ Treatment } & \multicolumn{5}{|c|}{ Mean \pm Standard Deviation (head) } \\
\hline & & 1 hour & 2 hours & 3 hours & 4 hours & 5 hours \\
\hline 1 & Aquadest + Tween 80 & $\begin{array}{c}0.50^{\mathrm{a}} \pm \\
0.58\end{array}$ & $1.00^{\mathrm{a} \pm} 0.00$ & $1.75^{\mathrm{a}} \pm 0.5$ & $\begin{array}{c}2.00^{\mathrm{a}} \pm \\
0.82\end{array}$ & $\begin{array}{c}2.25^{\mathrm{a}} \pm \\
0.96\end{array}$ \\
\hline 2 & Noticks & $\begin{array}{l}3.75^{c} \pm \\
0.96\end{array}$ & $\begin{array}{l}5.00^{c} \pm \\
0.00\end{array}$ & $\begin{array}{l}5.00^{\mathrm{b}} \pm \\
0.00\end{array}$ & $\begin{array}{l}5.00^{\mathrm{b}} \pm \\
0.00\end{array}$ & $\begin{array}{c}5.00^{c} \pm \\
0.00\end{array}$ \\
\hline 3 & $\begin{array}{c}\text { Permot Ethanol Extract } \\
\qquad \begin{array}{c}2.5 \%\end{array}\end{array}$ & $0.25^{\mathrm{a}} \pm 0.5$ & $1.50^{\mathrm{a}} \pm 1.73$ & $\begin{array}{l}2.50^{\mathrm{a}} \pm \\
2.08\end{array}$ & $\begin{array}{c}3 \cdot 50^{\mathrm{ab}} \pm \\
1.92\end{array}$ & $\begin{array}{l}3 \cdot 75^{\mathrm{b}} \pm \\
1.5^{\mathrm{o}}\end{array}$ \\
\hline 4 & $\begin{array}{l}\text { Permot Ethanol Extract } \\
5 \%\end{array}$ & $\begin{array}{l}0.00^{\mathrm{a}} \pm \\
0.00\end{array}$ & $1.25^{\mathrm{a}} \pm 0.50$ & $2.50^{\mathrm{a}} \pm 1.73$ & $4.25^{\mathrm{b}} \pm 1.5$ & $\begin{array}{c}4.75^{\mathrm{bc}} \pm \\
0.5\end{array}$ \\
\hline 5 & $\begin{array}{c}\text { Permot Ethanol Extract } \\
7.5 \%\end{array}$ & $1.75^{\mathrm{b}} \pm 0.50$ & $3.00^{b} \pm 1.41$ & $\begin{array}{l}5.00^{b} \pm \\
0.00\end{array}$ & $\begin{array}{l}5.00^{\mathrm{b}} \pm \\
0.00\end{array}$ & $\begin{array}{l}5.00^{c} \pm \\
0.00\end{array}$ \\
\hline 6 & $\begin{array}{l}\text { Permot Ethanol Extract } \\
10 \%\end{array}$ & $3.00^{c} \pm 1.41$ & $\begin{array}{c}4.25^{\mathrm{bc}} \pm \\
0.50\end{array}$ & $\begin{array}{l}5.00^{\mathrm{b}} \pm \\
0.00\end{array}$ & $\begin{array}{l}5.00^{\mathrm{b}} \pm \\
0.00\end{array}$ & $\begin{array}{c}5.00^{\mathrm{C}} \pm \\
0.00\end{array}$ \\
\hline
\end{tabular}

Note: Different superscripts in the same column, showing significant differences $(\mathrm{P}<0.05)$.

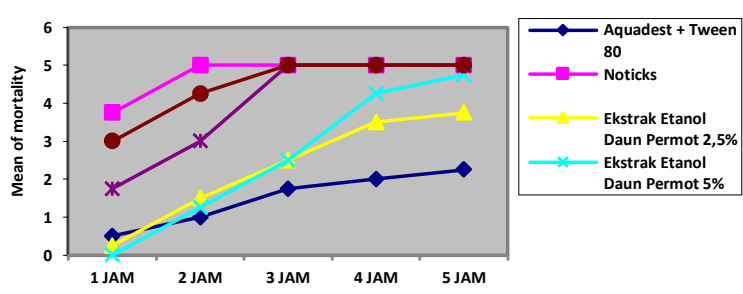

Figure 1. Graph of average mortality of $R$. sanguineus larvae

At a concentration of $2.5 \%$, larval mortality increased but until the fifth hour it had not reached the optimum value of $75 \%$. The use of ethanol extract of permot leaves with a concentration of $5 \%$ resulted in larval mortality that increased every hour but did not reach the optimum value until the fifth hour, only reaching $95 \%$. The use of ethanol extract of permot leaves with a concentration of $7 \cdot 5 \%$ and $10 \%$ has reached the optimum in the third hour. The use of $10 \%$ permot leaf extract is considered the most effective because in the second hour it has shown no significant difference with Noticks $^{\circledR}$ administration. The results of observations every 10 minutes for 5 hours in all.

treatments showed different results, but in the same treatment there was an increase in the average mortality of larvae. The use of Noticks ${ }^{\circledR}$ gave the average value of larval mortality at the 1st hour and has given the optimum value at the 3rd hour because it reaches a mortality percentage of $100 \%$. The probit test results gave an $\mathrm{LC}_{50}$ in the second hour of $2,000 \mathrm{mg} / 50 \mathrm{ml}$ equivalent to $4 \%$ with a lower limit of 1500 $\mathrm{mg} / 50 \mathrm{~mL}$ or equivalent to $3 \%$ and an upper limit of $2300 \mathrm{mg} / 50 \mathrm{~mL}$ or equivalent to $4.6 \%$. Lethal Concentration 50 at the fifth hour of $1200 \mathrm{mg} / 50$ $\mathrm{ml}$ is equivalent to $2.4 \%$ with an upper limit of $1500 \mathrm{mg} / 50 \mathrm{~mL}$ or equivalent to $2.95 \%$. These results indicate that the dose interval that can be used to kill $50 \%$ of $R$. sanguineus larvae in vitro is $2.4 \%-4.6 \%$. The probit test results gave an LC95 in the second hour of $3.250 \mathrm{mg} / 50 \mathrm{ml}$ equivalent to $6.51 \%$ with a lower limit of 2.780 $\mathrm{mg} / 50 \mathrm{~mL}$ or equivalent to $5.56 \%$ and an upper limit of $4.880 \mathrm{mg} / 50 \mathrm{~mL}$ or equivalent to $9.76 \%$. Lethal Concentration 95 at the fifth hour was $1.965 \mathrm{mg} / 50 \mathrm{ml}$ equivalent to $3.93 \%$ with a lower limit of $1.725 \mathrm{mg} / 50 \mathrm{ml}$ or equivalent to $3.45 \%$ and an upper limit of $4.120 \mathrm{mg} / 50 \mathrm{~mL}$ or equivalent to $8.24 \%$. These results indicate that the dose interval that can be used to kill $95 \%$ of $R$. sanguineus larvae in vitro is $5.56 \%$ as the lowest dose and $8.24 \%$ as the highest dose. The fastest time to reach the $\mathrm{LT}_{50}$ value is 0.91 hours by giving $10 \%$ permot leaf ethanol extract to kill $50 \%$ of the sample population, followed by $7.5 \%$ permot leaf ethanol extract with 1.36 hours, 5\% concentration with time 2.77 hours, and a concentration of $2.5 \%$ with a time of 2.96 hours. The higher concentration of ethanol extract of permot leaves indicates the secondary metabolite levels are also higher. The time required by the ethanol extract of permot leaves to kill $50 \%$ of $R$. sanguineus tick larvae in vitro was in the interval of 0.91 hours - 2.96 hours while the time needed to kill $95 \%$ of $R$. sanguineus larvae was at 2.37 intervals hours 9.21 hours. The probit test for Lethal Concentration 50 in the second hour was carried out at the four concentrations because the four concentrations had already begun to show an effect on larval mortality, while the fifth hour was carried out because it was the last observation time. 
Alkaloids work as a contact poison where the poison will be able to enter the digestive organs through direct contact with the tick's body. Alkaloids are toxic and can work to inhibit the work of the nervous system and damage cell membranes. The alkaloid group works by inhibiting the enzyme acetylcholinesterase, so that acetylcholine will accumulate at synapses. This causes the inhibition of the process of nerve transmission. In addition, alkaloids also cause inhibitory processes to chitin synthesis and inhibit hormone work (Soemirat, in Aseptianova et al., 2017). Flavonoids contained in permot leaves can damage the permeability of cell walls and inhibit the work of enzymes that affect the metabolic process in insects. Flavonoids have a mechanism of attacking several nerves in several vital organs, causing weakness in the tick's nerves. Flavonoids also act as respiratory inhibitors and disrupt energy mechanisms in mitochondria by inhibiting the electron transport system (Muta'ali and Kristani, 2015). Permot plants also contain saponins which can cause irritation to the cuticle of insects. The waxy coating that protects the insect's body and will be lost due to saponins and causes death due to loss of a lot of body fluids. Saponins can also cause digestive enzyme activity and absorption to decrease and interfere with the body's metabolic processes (Novizan, 2002).

\section{Conclusions}

Based on the results of the study, the ethanol extract of permot leaves (Passiflora foetida L.) can kill the larvae of $R$. sanguineus in vitro. The effective time and concentration to kill $R$. sanguineus larvae in vitro was a concentration of $5 \%$ at the fourth hour to a concentration of $10 \%$ at the third hour.

\section{References}

Aseptianova, T.F. Wijayanti, dan N. Nurina. 2017. Efektivitas Pemanfaatan Tanaman sebagai Insektisida Elektrik untuk Mengendalikan Nyamuk Penular Penyakit DBD. Bioeksperimen. Universitas Muhammadiyah Palembang. 3(2) : 10-19

Echeverri, F. V. Arango, W. Quinones, F. Torres, G. Escobar,Y. Rosero, dan R. Archbold. 2001. Passifloricins, Polyketides AlphaPhyrones From Passiflora foetida Resin. Phytochemistry. $56: 881-885$.

Muta'ali, R dan K. I. Purwani. 2015. Pengaruh Ekstrak Daun Beluntas (Pluchea indica) terhadap Mortalitas dan Perkembangan Larva Spodoptera litura F. J. Sains dan Seni ITS. 4 (2): $55-65$.

Novizan. 2002. Membuat dan Memanfaatkan Pestisida Ramah Lingkungan. Jakarta: Agro Media Pustaka. Hal. 20-27.

Paramita, N.M. D.P dan S. K. Widyastutin. 2019. Studi Kasus : Babaesiosis pada Anjing Persilangan. Indonesian Medicus Vet. 8(1) : 79-89.

Patel., S.S., H. Soni, K. Mishra, dan A.K. Singhai. 2011. Recent Updates on the Genus Passiflora: A Review. International J. of Res In Phytochemistry \& Pharmacol. 1(1): 1-16.

Patmasari, P.D., K.W. Astuti, dan N.K. Warditiani. 2013. Skrining Fitokimia Ekstrak Etanol 70\% Rimpang Bangle (Zingiber purpureum Roxb.). Fakultas Matematika dan Ilmu Pengetahuan Alam. Universitas Udayana. Denpasar. Hal. 2

Riyadi, Zulhar., Julizar, dan Rahmatini. 2018. Uji Efektifitas Ekstrak Etanol Biji Rambutan (Nephelium lappaceum L.) Sebagai Larvasida Alami pada Larva Nyamuk Aedes Aegypti. J. Kesehatan Andalas.7(2) : 233 239.

Susilowati, R.P. dan M.P. Sari. 2018. Uji bioinsectisida Ekstrak Daun Permot (Passiflora foetida) terhadap Kecoa Jerman (Blatella germanica). Jakarta: Fakultas Kedokteran, Universitas Kristen Krida Wacana. Hal 6 - 11.

Syakir, M. 2011. Status Penelitian Pestisida Nabati Pusat Penelitian dan Pengembangan Tanaman Perkebunan [Prosiding Semnas Pesnab IV]. Jakarta. Hal. 10.

Wardhana, A.H., A. Husein, dan J. Manurung. 2005. Efektifitas Ekstrak Biji Srikaya (Annona Squamosa L.) dengan Pelarut Air, Metanol, dan Heksan terhadap Mortalitas Larva Caplak Boophilus microplus secara In Vitro. Balai Penelitian Vet. 10 (2): 134-140. 